\title{
Bathymetry and sediments on the carbonate platform off western India: Significance of Halimeda bioherms in carbonate sedimentation
}

\author{
V Purnachandra RaO ${ }^{1,2, *}, \mathrm{~V}$ P Mahale ${ }^{2}$ and B Chakraborty ${ }^{2}$ \\ ${ }^{1}$ Department of Civil Engineering, Vignan's University, Vadlamudi, Guntur 522 213, India. \\ ${ }^{2}$ CSIR-National Institute of Oceanography, Dona Paula, Goa 403 004, India. \\ *Corresponding author.e-mail: vprao55@gmail.com
}

MS received 12 October 2017; revised 7 February 2018; accepted 9 February 2018; published online 29 September 2018

Bathymetry across the carbonate platform off western India indicated small-size pinnacles and their lateral coalescence into 2 -6-m high mounds landward, and linear elongated carbonate ridges and troughs, mounds and banks up to a height of 20-m seaward of the platform. Seismic data indicated that these mounds were transparent with no rigid internal structure and can be defined as bioherms. The sediments were abundantly aragonite faecal pellets, Halimeda grains and ooids and their radiocarbon ages ranged from 11 to $7.5 \mathrm{ka} \mathrm{BP}$. It appears that the growth of Halimeda bioherms on the platform was facilitated by intense upwelling during the early Holocene. The terrigenous sediments brought by rivers were deposited in the inner shelf and have not affected the growth of bioherms. It is estimated that the platform comprises at least $1.85 \mathrm{Gt}$ of mass $\mathrm{CaCO}_{3}$ accumulated during the early Holocene and comparable to those on the Great Barrier Reef. Halimeda bioherms produce abundant carbonate sediments and their growth period represents a geological carbonate sink and release of high $\mathrm{CO}_{2}$ to the atmosphere. Detailed shallow seismic studies and sediment cores are needed to quantify the exact mass content of $\mathrm{CaCO}_{3}$ and model climate change during the early Holocene.

Keywords. Halimeda bioherms; early Holocene; upwelling; carbonate platform; western India.

\section{Introduction}

Halimeda is a photosynthetic, reef-building calcareous green macroalgae, abundant in tropical, shallow marine environments (Hillis-Colinvaux 1980). It has many leafed-like segments and grows with the increased segments. The segments released by spontaneous disaggregation of Halimeda accumulate on the seafloor. The swift initial calcification of segments (up to $50 \%$ of new segment weight composed of $\mathrm{CaCO}_{3}$ within $48 \mathrm{hr}$ ) and sporadic subsequent infill of inter-utricular spaces with aragonite crystals allow this alga as an important contributor of sand- to mud-size carbonate sediments (Multer 1988a). Halimeda sediments accumulate over seafloor as meadows, draperies, banks and thick mounds called bioherms (Freile 2004). The mounds grow both vertically and laterally until they coalesce laterally, or form unusual, large sediment banks. Despite Halimeda grows at water depths between 2 and $150 \mathrm{~m}$ (Multer 1988b), the present day Halimeda is extensive in relatively deep water $(20-50 \mathrm{~m})$ and forms bioherms up to a height of $15-20 \mathrm{~m}$ in the northern Great Barrier Reef (NGBR) (Orme et al. 1978; Marshall and Davies 1988), 1.5-14-m thick deposits within the Swains Reef of the southern Great Barrier Reef (Searle and Flood 1988), 20-50-m height in 
the Sunda shelf, Indonesia (Phipps and Roberts 1988; Roberts et al. 1988) and 20-30-m height (and some reaching as high as $140 \mathrm{~m}$ ) in the southwestern Caribbean (Hine et al. 1988), 15-m thick deposits on the Fly River Delta, Gulf of Papua, New Guinea (Harris et al. 1996) and up to 55-m thick deposits on submerged carbonate platforms in the Timor Sea, northwestern Australia (Heyward et al. 1997). Halimeda preferentially occurs in relatively low-energy environments but reported even in the reef front, inter-reef and back reef areas. Halimeda has been discovered in many well-known atolls throughout the world, including the Grand Bahamas Bank (Hoskin et al. 1986), Caribbean Sea reefs (Hine et al. 1988) and in some atoll lagoons in the Pacific Ocean (Milliman 1974), the Great Barrier Reef (Orme and Salama 1988), Bermuda (Wefer 1980) and in the Mediterranean region (Fornos et al. 1992). Recent investigations on the Great Barrier Reef and other atolls showed that the Halimeda reefs cover much more area than the previously estimated (Liddell et al. 1988; Rees et al. 2005, 2007; Xu et al. 2015). Halimeda not only produces abundant carbonate sands and muds but are also important sources of nutrition for many herbivorous fish. Some species of parrotfish feed preferentially on Halimeda (Overholtzer and Motta 1999), but the preference is dependent on $\mathrm{CaCO}_{3}$ content and algal chemical defences (Hay et al. 1988; Paul and van Alstyne 1988; Pennings and Paul 1992). Halimeda is highly susceptible to reduced $\mathrm{pH}$ and aragonite saturation state but the magnitude of these effects is species specific. Some species of Halimeda suffered net dissolution and reduction in photosynthetic capacity, while others did not calcify and alter the photophysiology in experimental treatments (Price et al. 2011).

The importance of understanding the Halimeda bioherms is two-fold: first, Halimeda is known to occur since the Cretaceous (Elliot 1965; HillisColinvaux 1980; Hillis 1997), but does not have a rich fossil record until the Holocene. The mound building by Halimeda was first recognised in 1978 in the Great Barrier Reef (Orme et al. 1978), since then several occurrences of Halimeda bioherms of Holocene and recent were reported in the Indo-Pacific region (Orme et al. 1978; Orme 1985; Phipps et al. 1985; Scoffin and Tudhope 1985; Hillis-Colinvaux 1986; Roberts et al. 1987a, b; Hine et al. 1988; Marshall and Davies 1988; Roberts and Phipps 1988; Milliman 1993; Rao et al. 1994). Subsequently, Braga and Martin (1993) and Braga et al. (2015) reported the ancient Halimeda mounds of Miocene ( 6.0 Ma) in the southeastern Spain. The limited fossil record of Halimeda mounds and several Holocene occurrences hint at specific conditions (climate and environmental changes) responsible for their favoured growth and preservation. As these conditions change locally, one needs to identify the factors controlling the Halimeda bioherms precisely for each deposit. Second, Halimeda is capable of generating between 3 and 19 crops per year (Hillis 1991) and produces abundant carbonate sediments, over $2 \mathrm{~m} / 1000$ yr (Milliman 1993). The Halimeda bioherms thus contain much more carbonate sediment, sometimes up to four times, higher than that of the adjacent coral reef (Rees et al. 2007). The Halimeda bioherms at many locations are associated with coral reef carbonates and as a consequence the significance of Halimeda in the global carbonate budget, independent of coral reefs, has not yet been precisely estimated. The identification of Halimeda bioherms is usually based on bathymetric details, extensive seismic data and sediment components (Orme et al. 1978; Orme and Salama 1988; Phipps et al. 1985; Roberts et al. 1987a, b; Hine et al. 1988; Marshall and Davies 1988; Kirkland et al. 1993; Braga et al. 2015). Lateral coalescence of pinnacles and transparent internal fabric of the mounds arising from the hard bottom are characteristics of bioherms. In this paper, the extensive bathymetric data and limited shallow seismic data collected simultaneously along the east-west (E-W) profiles and components of sediment at different stations from the carbonate platform off northwestern India were used to identify the bioherms. The purpose of this paper is to better understand the factors controlling the formation of Halimeda bioherms and estimate the mass calcium carbonate accumulated during the early Holocene.

\subsection{Study area}

The carbonate platform is located on the outer continental shelf off northwestern margin of India and oriented in the NW-SE direction at latitudes between $17^{\circ}$ and $21^{\circ} \mathrm{N}$ (figure 1 ). It has a maximum width of $\sim 110 \mathrm{~km}$ at the centre, tapering on either end and covering an area of $\sim 28,336 \mathrm{~km}^{2}$ between 80- and 90-m depth contours. It is also known as 'Fifty Fathom Flat', but water depths on the platform vary from 75 to $115 \mathrm{~m}$ (Rao et al. 1994). The carbonate platform is unique as it constitutes only $<10 \%$ terrigenous sediments (Rao et al. 


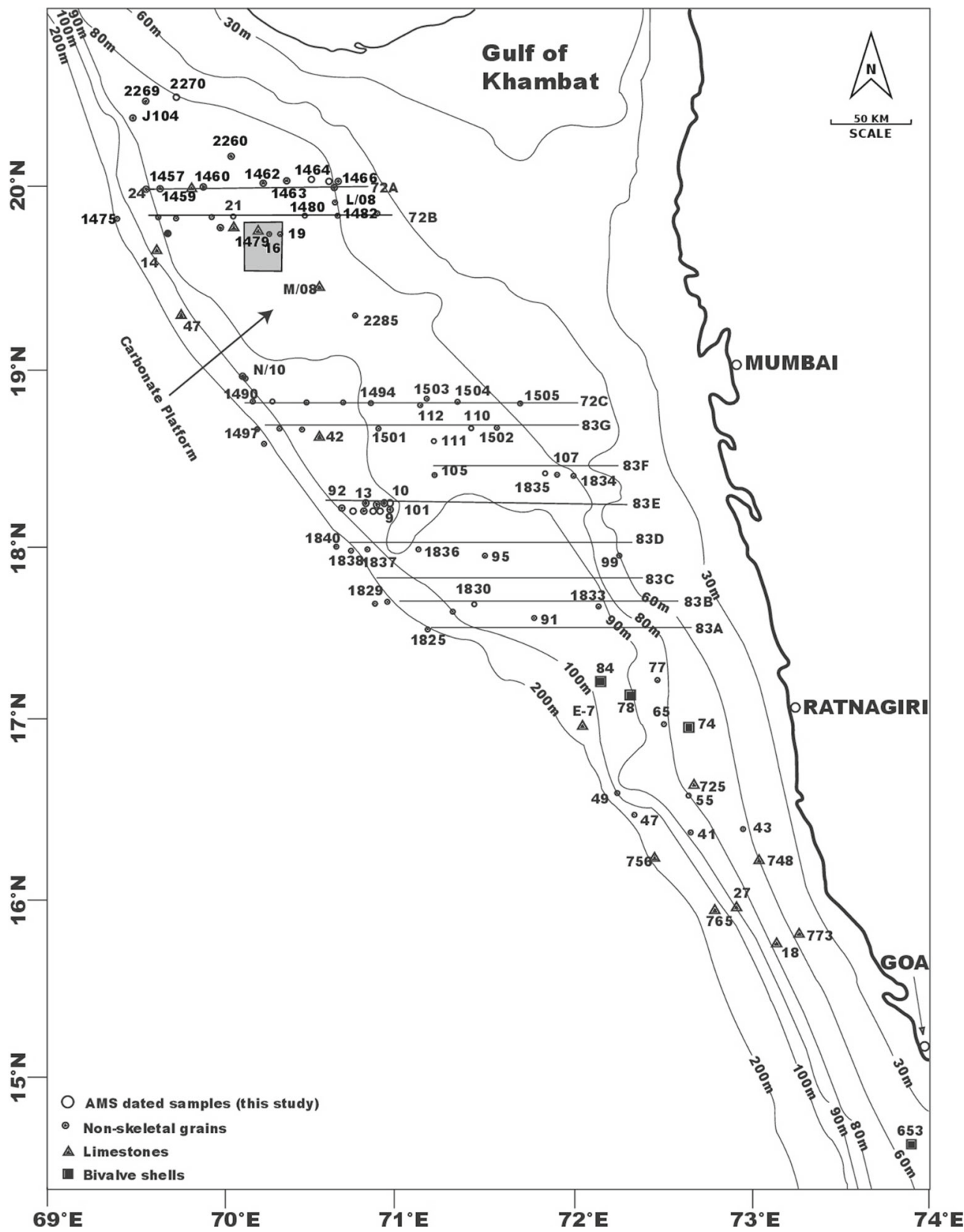

Figure 1. Location map of the carbonate platform on the western margin of India. Location of samples, bathymetric (E-W) lines, and area (box) where multibeam bathymetry was carried out are also shown.

1994) despite the major rivers being located at its proximity (figure 1). For example, on the northeast of the platform, the Narmada and Tapti rivers discharge annually $\sim 60$ million $\mathrm{m}^{3}$ of water and the abundant suspended sediments into the Arabian Sea (Rao 1975). Similarly, $400 \mathrm{~km}$ north of the platform, the Indus river discharges huge sediment load into the Arabian Sea and the Indusborne sediments are known to extend $1500 \mathrm{~km}$ from its mouth (Nair et al. 1982). The limited terrigenous sediments and the abundant carbonate sediment deposition on the platform during the early Holocene make the platform amazing and invoke more understanding on the deposition of terrigenous sediments during this period. What factors influenced the carbonate growth? Investigations on bathymetry and sediments of the platform would offer valuable information on factors favouring the formation of Halimeda bioherms that developed in open, shallow marine settings.

The topography and associated sediments in a limited area of the carbonate platform were investigated by Nair and Pylee (1968), Nair (1971, 1975), Nair et al. (1979) and Nair and Hashimi 

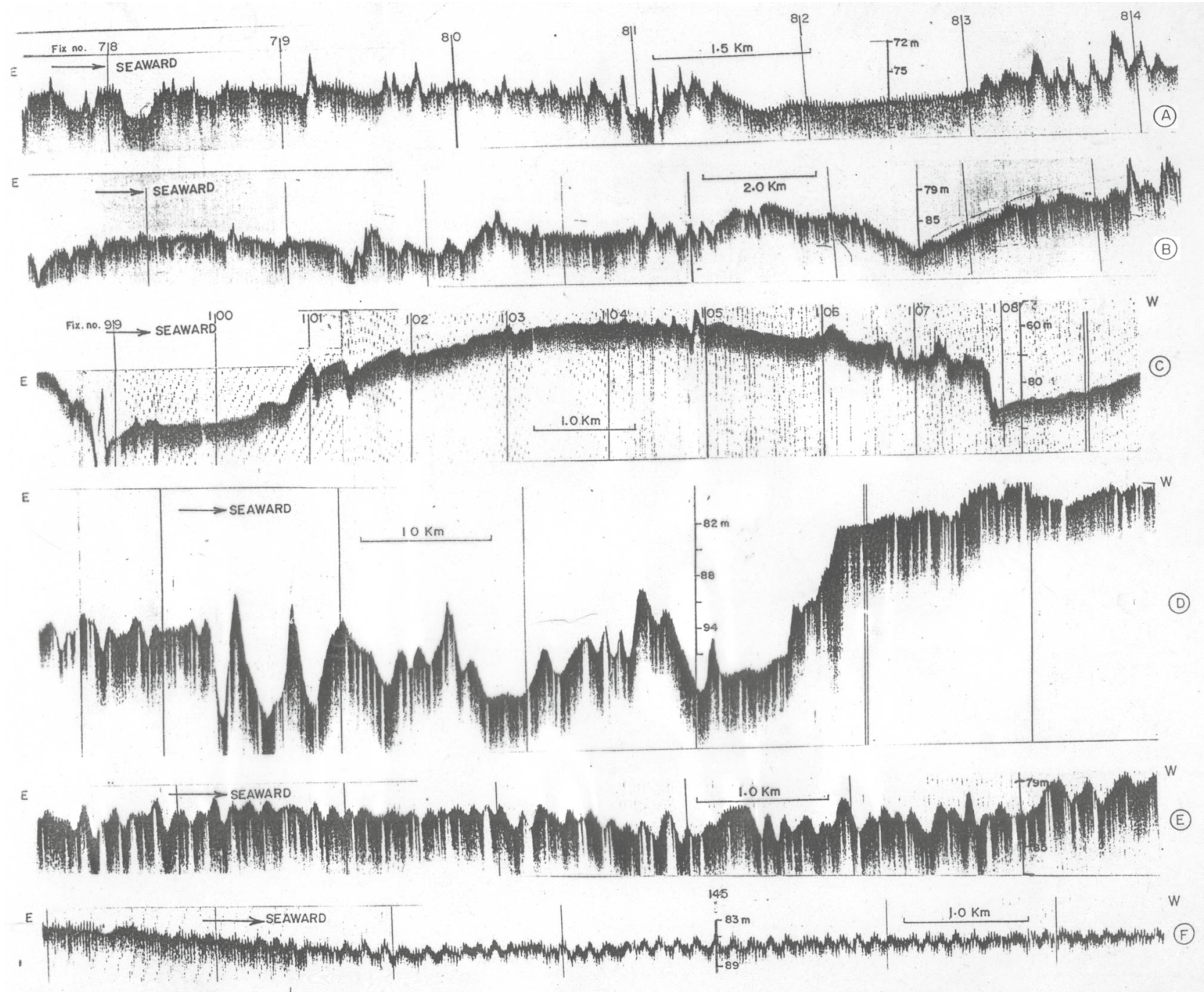

Figure 2. Bathymetry of the part of the E-W profiles of the platform along $(\mathbf{a}-\mathbf{c}) 72 \mathrm{~A}$ and $(\mathbf{d}-\mathbf{f}) 72 \mathrm{~B}$.

(1981). Subsequently, Rao et al. (1994, 2003a, b), Rao and Veerayya (1996) and Rao and Milliman (2017) investigated the bathymetry, carbonate sediments and sedimentary rocks on the platform and reported Halimeda grains, ooids and faecal pellet-dominated sediments, and inferred sea level changes during the late Quaternary. The factors responsible for the formation of Halimeda bioherms and calcium carbonate budget on the platform after the last glacial maximum have not yet been attempted. This study fills the gap and details the importance of Halimeda bioherms on the platform and estimates the carbonate budget during the early Holocene.

\section{Materials and methods}

During the 72 and 83 cruises of R V Gaveshani, a single-beam echo-sounding (SBES) system was operated for acquiring bathymetric data along the pre-determined $\mathrm{E}-\mathrm{W}$ profiles of the platform (figure 1). The SBES system onboard was Kelvin Hughes MS-45. A bar check was carried out before the commencement and after the completion of the surveys. The SBES system operates at a frequency of $30 \mathrm{kHz}$. The bathymetry data were available in the form of thermal records (figures 2-4).

Multibeam echo-sounding (MBES) system was operated for acquiring the Swath bathymetry data on the carbonate platform off Tarapur, west coast of India (see box in figure 1) during four cruises of the Coastal Research Vessel Sagar Sukti in the year 2007. The MBES system installed was the EM 1002 of Kongsberg AS, Norway, having 111 receive beams that are spaced at an interval of $2^{\circ}$ over a $150^{\circ}$ sector. The operating frequency of the system was $95 \mathrm{kHz}$. Using both the amplitude (inner beams) and phase (outer beams) 


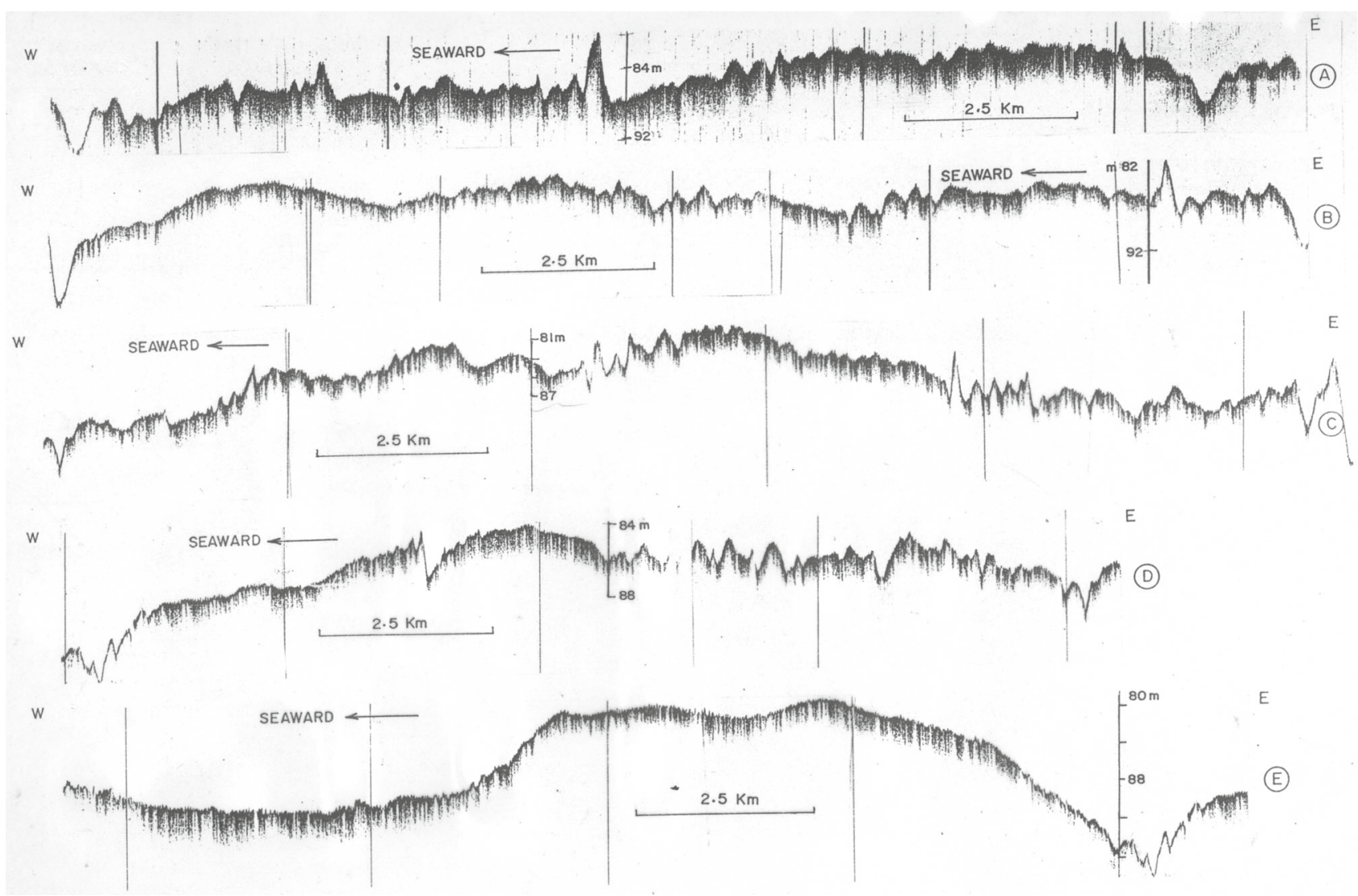

Figure 3. Bathymetry of the platform along E-W profile $83 \mathrm{~F}$.

detection methods, the multibeam system is capable of achieving the depth resolution $(2-8 \mathrm{~cm})$. Post-processing corrections include the removal of tide effects and depth outliers and gridding of the bathymetric data. Finally, three profiles were extracted along the north-south orientation from the 10-m gridded bathymetry data (figure 5), which has been depicted as one-dimensional profiles (figure 6).

High-resolution shallow seismic profiling was also carried out simultaneously with the acquisition of echo-sounding data during the 72 and 83 cruises of R V Gaveshani, using an ORE sub-bottom profiler. The system consists of an ORE Transceiver model 140 and a hull-mounted nine transducer arrays. An EPC Recorder model 3200 was used for recording a 49-cm wide dry paper (figure 7). Here, the system was operated mostly for greater penetration at $3.5 \mathrm{kHz}$ and occasionally switched over to $7.0 \mathrm{kHz}$ for observing the differences in sediment strata.

Surface sediments were also collected using the Van Veen Grab, during the 72 and 83 cruises of $\mathrm{R} \mathrm{V}$ Gaveshani, at fixed intervals along the E-W echo-sounding profiles. The sediments collected in other cruises of ORV Sagar Kanya were also used (figure 1). A total number of 78 samples were investigated in this study. The sediments were wet sieved using 230 mesh sieves and coarse fraction $(>63 \mu \mathrm{m})$ was dried and examined under a binocular microscope. Components were identified and 300 grains were counted for different components of sediments. Sediment components were abundantly non-skeletal. Halimeda grains became rounded and small in size because of dynamic environment at the seafloor and can be recognised only in thin sections. Therefore, the term non-skeletal was used to include faecal pellets, peloids, ooids and Halimeda grains. The percentage distribution of non-skeletal grains and shells and shell fragments is shown in figure 8( $\mathrm{a}$ and $\mathrm{b}$ ). Faecal pellets and sections of Halimeda grains are shown in figure 9(a and b), respectively. No new samples were radiocarbon dated for the purpose of this paper. Sediment samples radiocarbon dated earlier were used and the detailed procedure for radiocarbon dating was given in Rao et al. (2003b) and Rao and Milliman (2017). The calibrated ages (ka BP) of samples so far dated on the platform are shown in figure 10. 


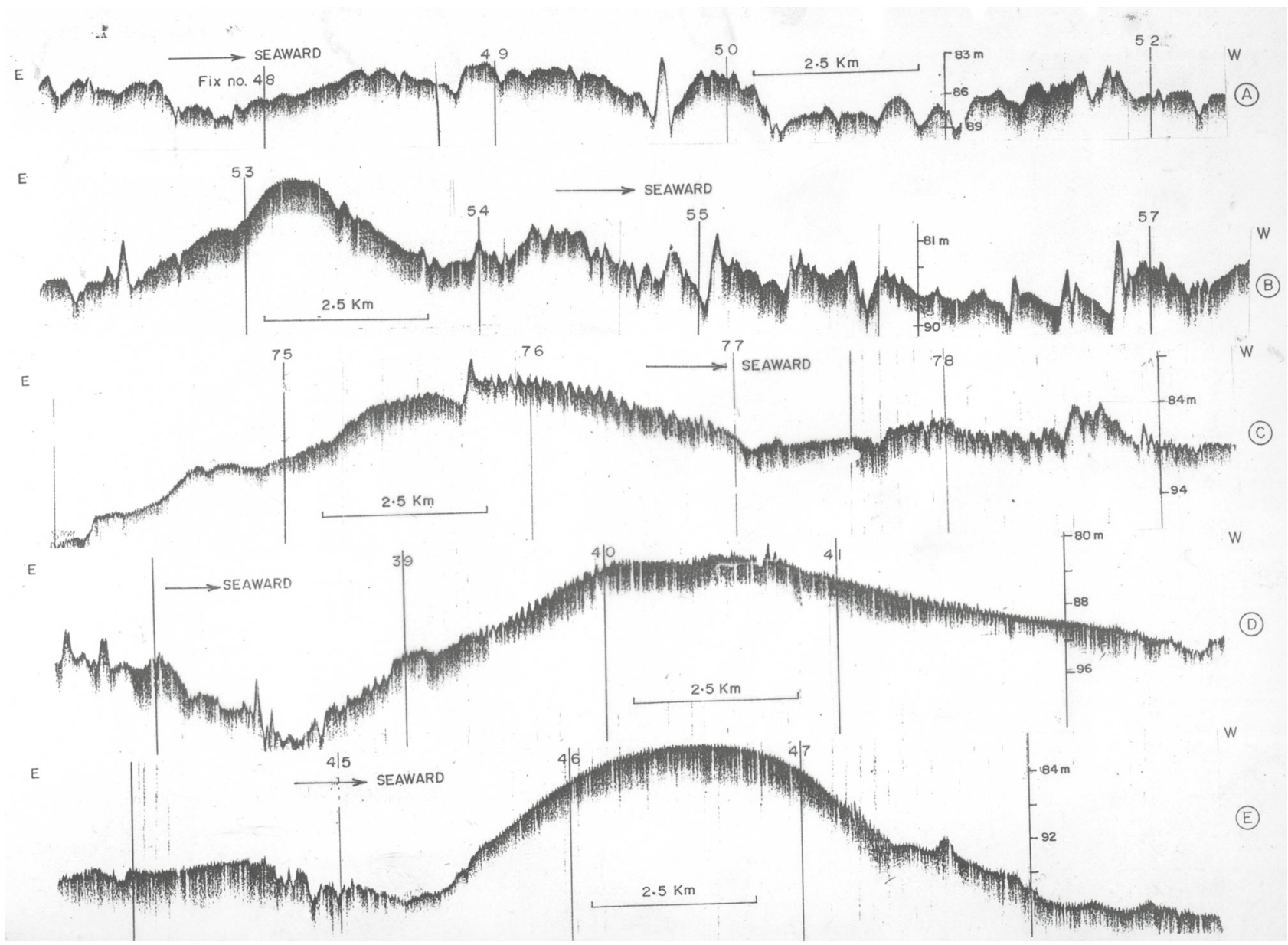

Figure 4. Bathymetry of the part of the E-W profiles of the platform along (a-c) $83 \mathrm{D},(\mathbf{d}) 83 \mathrm{E}$ and (e) G.

\section{Results}

\subsection{Bathymetry}

The bathymetry data are available along the 11 $\mathrm{E}-\mathrm{W}$ profiles across the platform (figure 1) and important profiles are shown in figures $2-4$. The platform, in general, exhibits rugged, sea floor topography with low relief $(\sim 2-6 \mathrm{~m})$ features in the eastern part $(72 \mathrm{~A}, \mathrm{~B}$ and $\mathrm{C})$ and the high relief features $(15-20 \mathrm{~m})$ in the western part $(83 \mathrm{D}$, $\mathrm{E}, \mathrm{F}$ and $\mathrm{G}$ ). The slope of the platform along its western edge was gentle in the northern part, but abruptly steep in the southern part. Buried pinnacles of $6-8-\mathrm{m}$ high have been reported at the eastern edge of the platform (Rao et al. 1994) and at the transition between terrigenous clays and carbonate sediments.

The bathymetric features in the northern profiles (figure 2a) showed pinnacles or coalesced pinnacles of $\sim 2-6-\mathrm{m}$ height, separated by flat floors. The pinnacles were smaller at landward but larger and laterally coalesced into mounds seaward. Parallel profiles indicated that the position of a broad and well-developed mound at seaward in profile $72 \mathrm{~A}$ (figure 2c) corresponds to a depression with the well-defined individual and coalesced mounds in profile $72 \mathrm{~B}$ (figure $2 \mathrm{~d}$ ). The individual mounds were $\sim 1-\mathrm{km}$ wide and 6 -m high, whereas the coalesced mounds ranged from 3 to $7 \mathrm{~km}$ in width and up to $25 \mathrm{~m}$ in height (figure 2c). A series of shoals with the well-defined mounds were also found in profile $72 \mathrm{~B}$. The seafloor becomes smoother and smoother with small-scale ripples as one proceeds seaward, closer to the western edge of the platform (figure $2 \mathrm{e}$ and $\mathrm{f}$ ).

A continuous bathymetric profile of $83 \mathrm{~F}$ (figure 3) and part of the profiles at seaward sections in profiles $83 \mathrm{D}, \mathrm{E}$ and $\mathrm{G}$ (figure 4) show distinct surface expressions of the mounds. In profile $83 \mathrm{~F}$, the mounds were developed on wide tracts. From figure $3(\mathrm{a}$ and $\mathrm{b})$, it appears that the mounds were initially thinner and relatively less wide landward and their size and complexity 


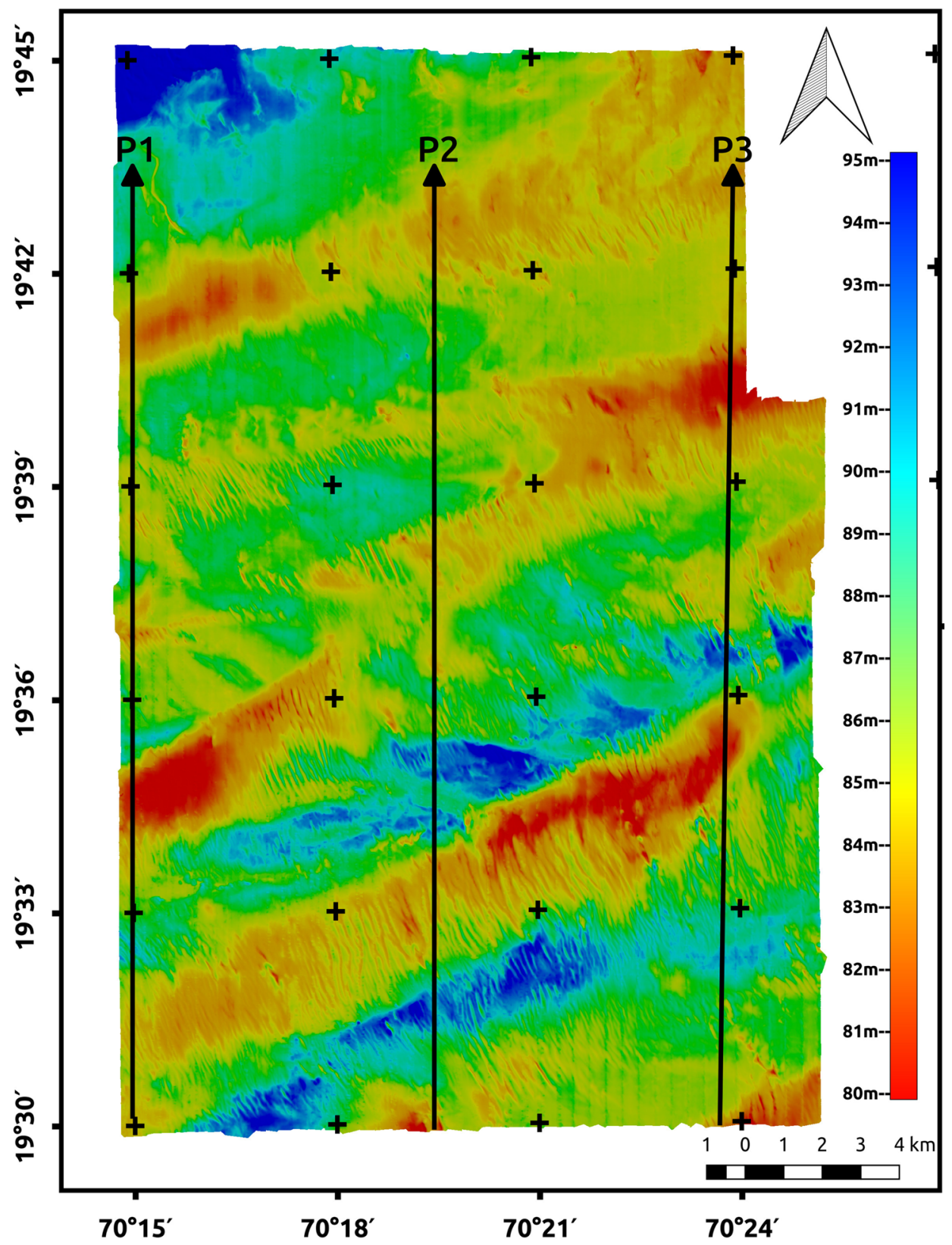

Figure 5. Multibeam bathymetry of the area (box) shown in figure 1.

increase offshore; the mounds coalesced into large composite mounds with maximum thickness at the centre (see figure $3 \mathrm{c}$ and $\mathrm{d}$ ). It is evident that the tops of the mounds are not at same depths as one proceeds offshore. The smaller mounds on the eastern end were $3-\mathrm{km}$ wide, whereas those on the western end were coalesced and $\sim 5-7-\mathrm{km}$ wide and $15-20 \mathrm{~m}$ in height with smoother top surfaces (figure 3e). Figure 4(a and b) shows the part of the profile starting from the eastern end in profile $83 \mathrm{G}$, and figure $4(\mathrm{c}, \mathrm{d}$ and e) shows small portions at the western end in profiles $83 \mathrm{D}$ and $83 \mathrm{E}$. The crest portions of some mounds were smooth but showed well-preserved, small symmetrical ripples either on their western flanks or eastern flanks. The mounds were asymmetric on seaward flanks in profile $83 \mathrm{D}$ (figure 4c).

Detailed multibeam bathymetry carried out in a small area on the platform (see box in figure 1) showed the linear algal ridges and troughs parallel to one another in the east-west direction and their coalescence at places across the platform (figure 5). The ridges raised from $85 \mathrm{~m}$ water depth to $95 \mathrm{~m}$ along their length. The width of the ridges also varied and much wider when coalesced. The north-south profiles in the same area showed 


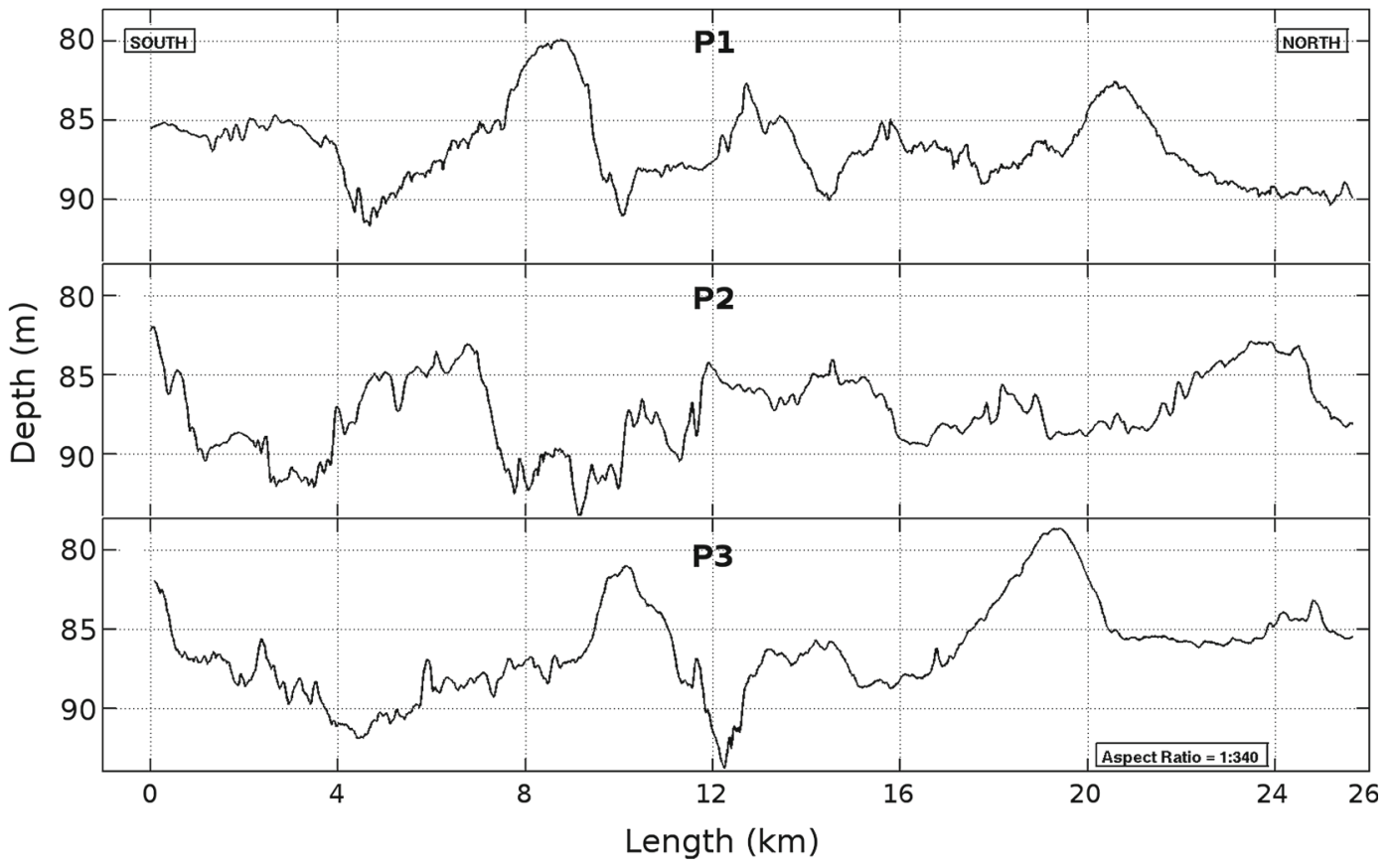

Figure 6. Bathymetry of the N-S profiles (P1, P2 and P3) shown in multibeam image.
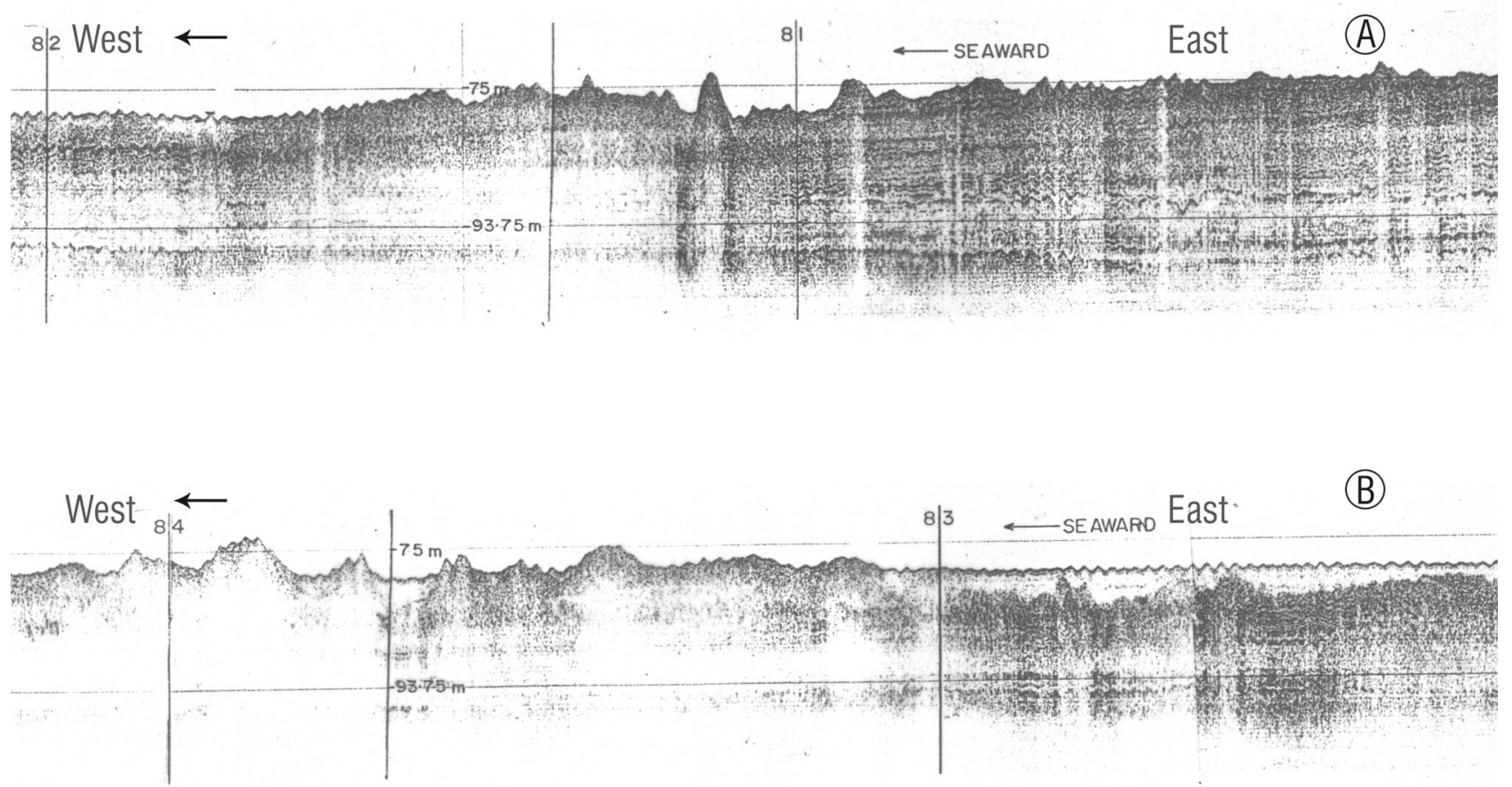

Figure 7. Seismic profiles showing transparent mounds.

mounds and coalesced mounds (figure 6). The individual mounds were up to $12 \mathrm{~m}$ in height and 5-7 $\mathrm{m}$ in height when coalesced. The limited seismic data were available. The pinnacles and coalesced pinnacles were represented by transparent mounds in the seismic profiles and do not exhibit a clear internal framework (figure $7 \mathrm{a}$ and $b)$.

\subsection{Sediments}

The platform consisted of abundant carbonatedominated (up to 90\%) sandy sediments. The sediment samples everywhere on the platform composed of non-skeletal grains, shells and shell fragments. The percentage of non-skeletal grains increased seaward while that of shells and shell 


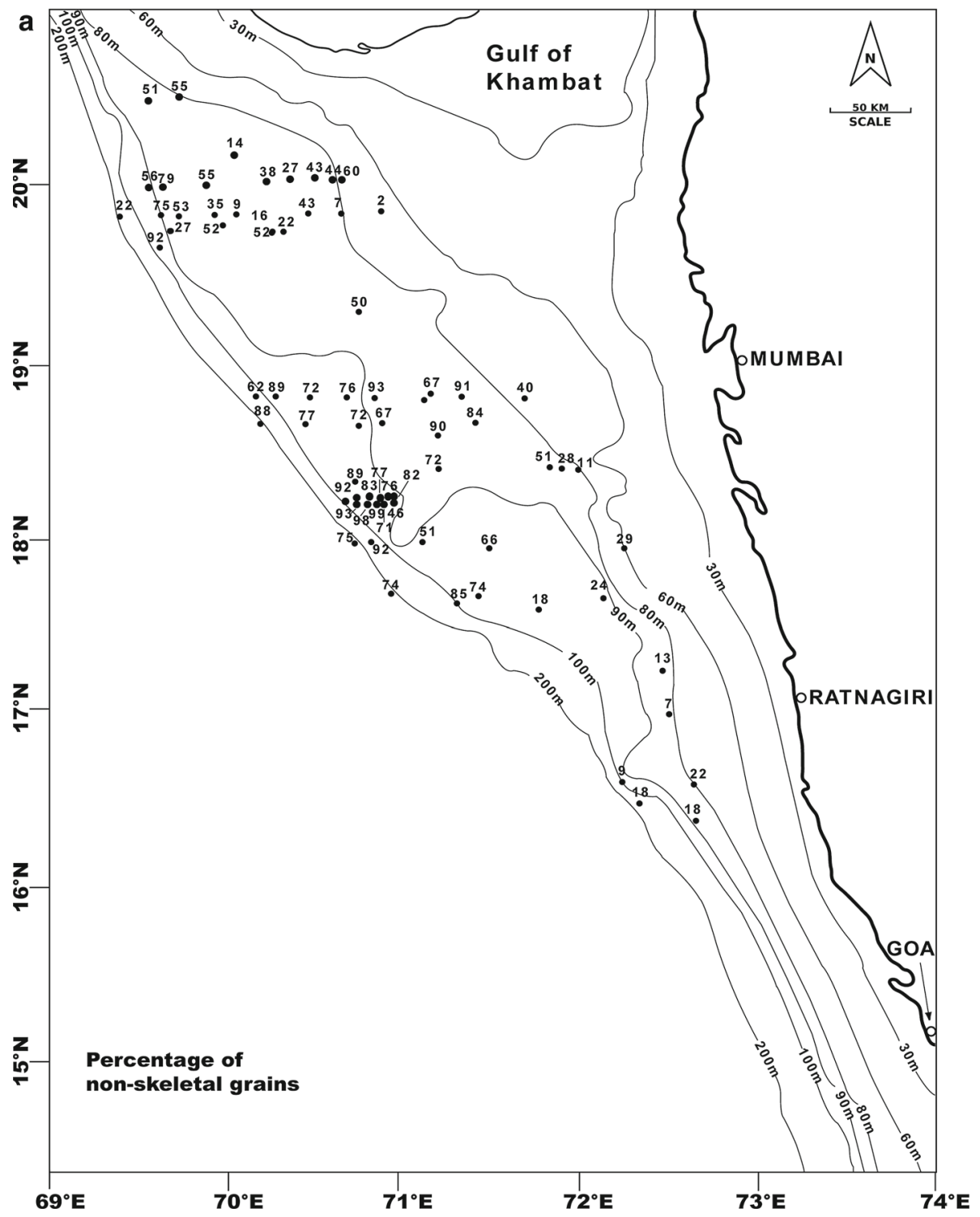

Figure $8(\mathrm{a})$. The distribution of non-skeletal grains.

fragments increased (up to $36 \%$ ) landward of the platform (figure $8 \mathrm{a}$ and $\mathrm{b}$ ). Thin sections of the non-skeletal grains indicated the abundant crustacean faecal pellets, followed by Halimeda grains and ooids (figure 9a and b). Boring cavities are extensive on many particles. The calibrated radiocarbon ages of carbonate samples on the platform ranged from 11 to $7.56 \mathrm{ka} \mathrm{BP}$. The samples from the slope and a few samples from the platform showed radiocarbon ages between 12.33 and $13.28 \mathrm{ka} \mathrm{BP}$ and 21.04 ka BP (figure 10).

\section{Discussion}

Carbonate reefs, mounds and build-ups are important components of the sedimentary rock record and occur both in deep (up to $1000 \mathrm{~m}$ ) and shallow marine settings (Henriet et al. 2011). They are formed by a variety of organisms such as corals, stromatophorids, sponges, bryozoans, crinoids, algae and rudists (Riding 2002). Besides, mud mounds as rigid framework reefs produced by in-situ organisms (degradation of delicate skeletons, microbial production) and formed by an inorganic accumulation of mud have also been reported (Pratt 1995; Wood 2001). Carbonate mounds provide unique archives, and the understanding of the entire architecture of a mound is fundamental in the identification of past environmental changes. Recent carbonate mounds stand as natural laboratories to link the build-up history and architecture to high-resolution sequence stratigraphy. High-energy conditions and the 


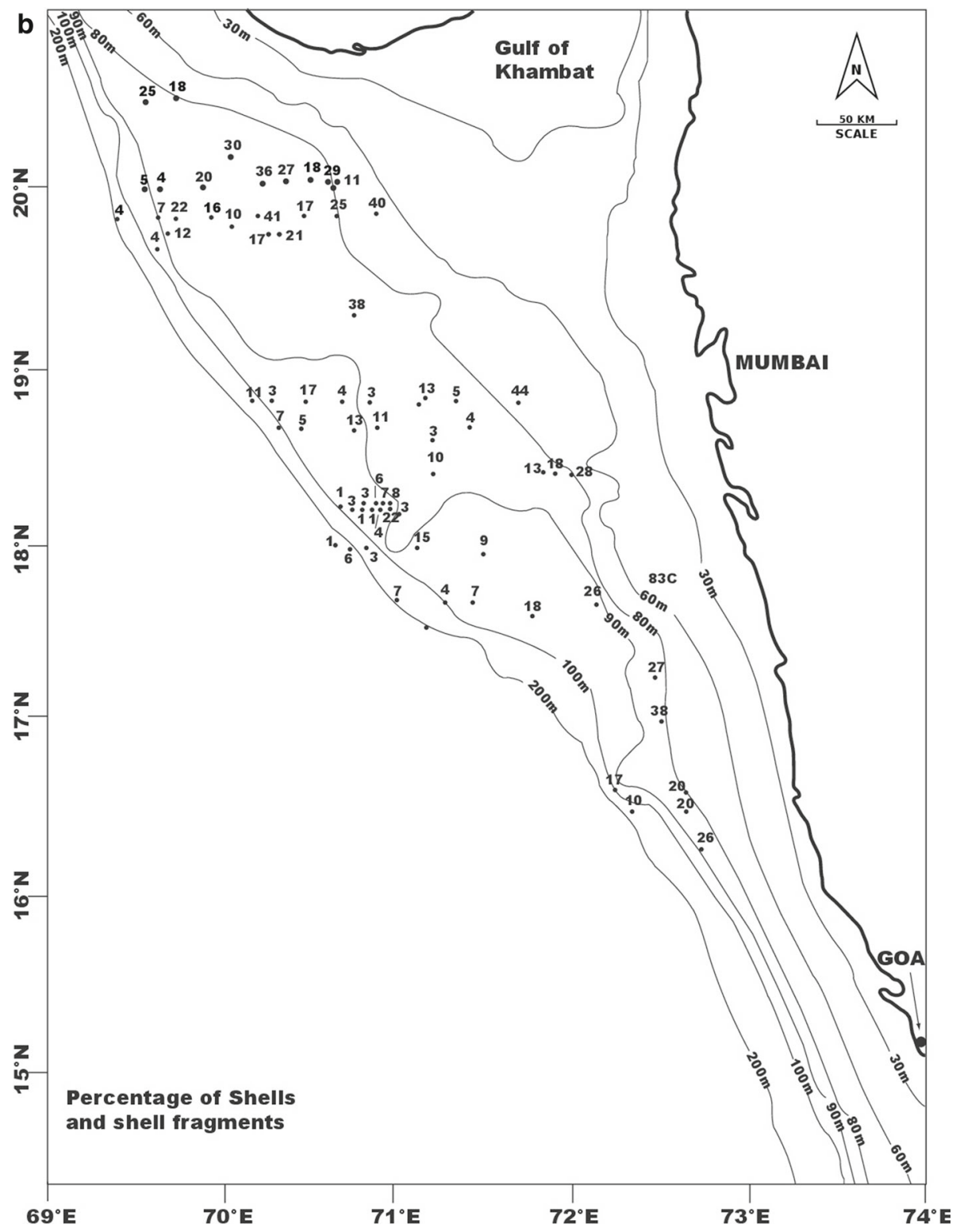

Figure $8(\mathrm{~b})$. The distribution of shells and shell fragments on the carbonate platform.

presence of organisms in mounds would be distinctive indicators for the origin of shallow water mounds.

\subsection{Environmental settings inferred from bathymetric features}

The bathymetric features comprising pinnacles, elongate carbonate ridges and troughs, mounds and banks occur on the platform (figures 2-6). The width and height of these geomorphic features vary spatially. Roberts et al. (1988) defined bioherms as mounds that have relief above the seafloor, but do not exhibit a clear, internal framework. In one $\mathrm{E}-\mathrm{W}$ profile (figure 2), one can see individual pinnacles and their coalescence with the neighbouring pinnacles initially as small mounds of $2-4-\mathrm{km}$ wide and then into large lens-shaped mound seaward (figure 2c). In another profile, mounds are thickest at the centre and the small individual and adjacent mounds frequently merge to form 10-15-m high mound (figure 3 ). In other words, large mounds are probably the final product formed by fusing of the individual mounds (figure 3). In seismic profiles, mounds are transparent with no rigid internal structure (figure 7) and therefore can be defined as bioherms. Such features have been reported previously and attributed to Halimeda bioherms. For example, Orme et al. (1978) and Orme and Salama (1988) reported 

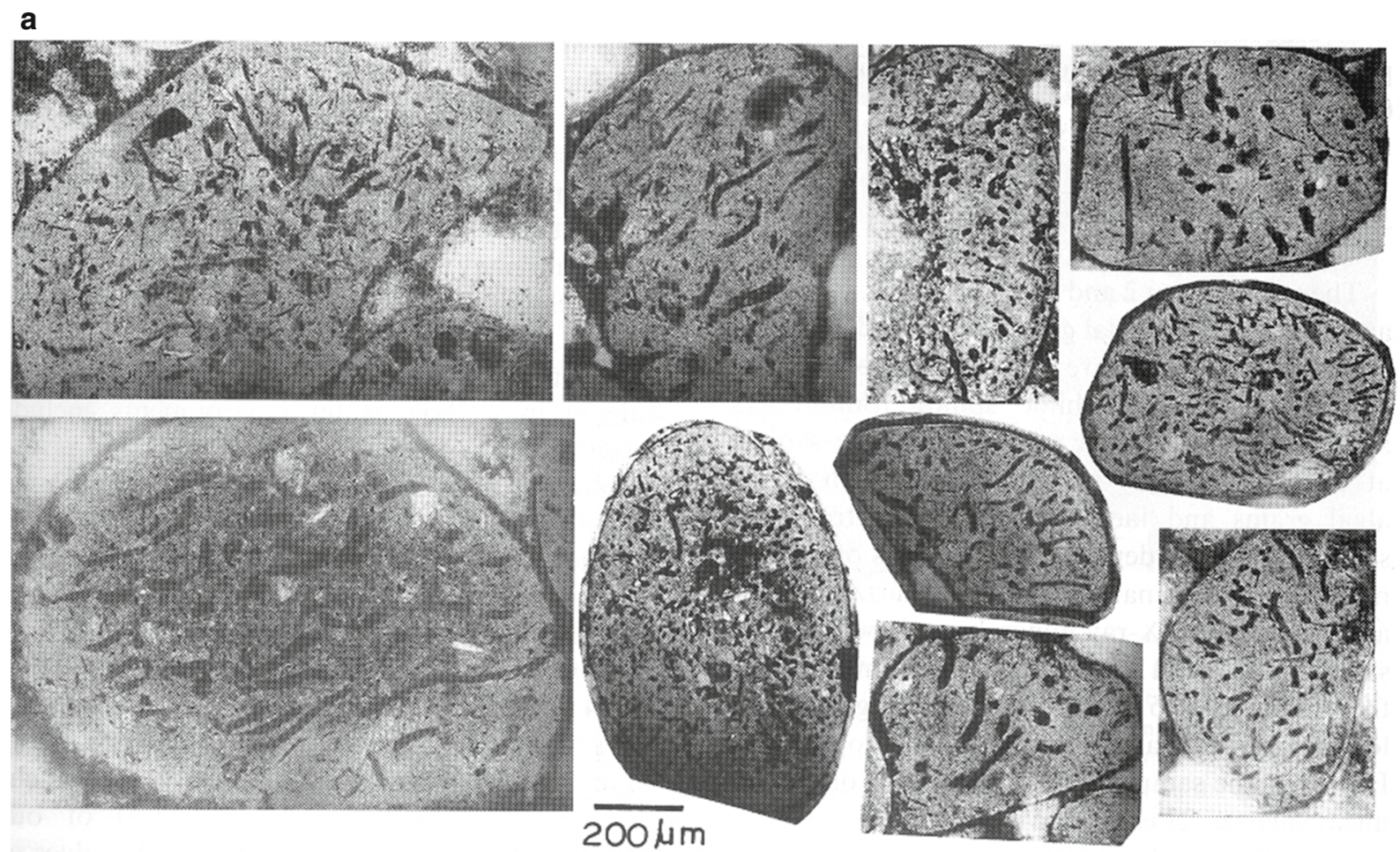

b

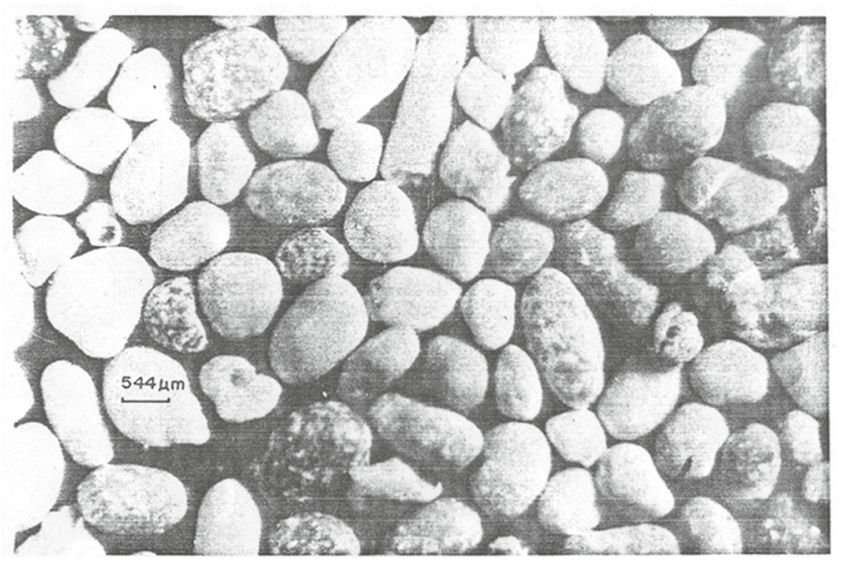

Figure 9. Sediments showing (a) faecal pellets and (b) Halimeda grains.

Halimeda bioherms in the form of banks and ridges with troughs and hollows, whereas Drew and Abel (1985) described them as discrete circular mounds and parallel ridges in the NGBR. Roberts et al. (1987a) reported the elongated ridges and valleys to hummocky mounds as a characteristic of Halimeda bioherms on the Sunda shelf, Java Sea. Hine et al. (1988) reported the Halimeda bioherms as mounds with lens-like geometry in the Caribbean region. The phylloidal algal mounds from the late Paleozoic in the Sacramento mountains, New Mexico (Kirkland et al. 1993) and Halimeda bioherms from the upper Miocene reefs of the Sorba Basin, southeastern Spain (Braga et al. 2015) also exhibited lenticular morphology and are considered analogues to their Holocene counterparts in the Great Barrier Reef. Bedding is also a common feature visible in seismic sections (figure 7a). The bioherms on this platform are relict. They showed well-developed mounds with lenticular morphology landward, and well-preserved surface characters of the mounds and banks seaward and therefore are in-situ accumulations (figures $2 \mathrm{c}$ and $3 \mathrm{c}$ ).

The larger and broader mound-shaped features with a maximum height of $\sim 15 \mathrm{~m}$ on the western edge (figure $4 \mathrm{c}-\mathrm{e}$ ) and well-developed pinnacles on the eastern edge of the platform (figure $2 \mathrm{a}$ and $\mathrm{b}$ ) suggest significant growth at seaward rather than landward of the platform. Further, both symmetrical as well as asymmetrical mounds occur on the 


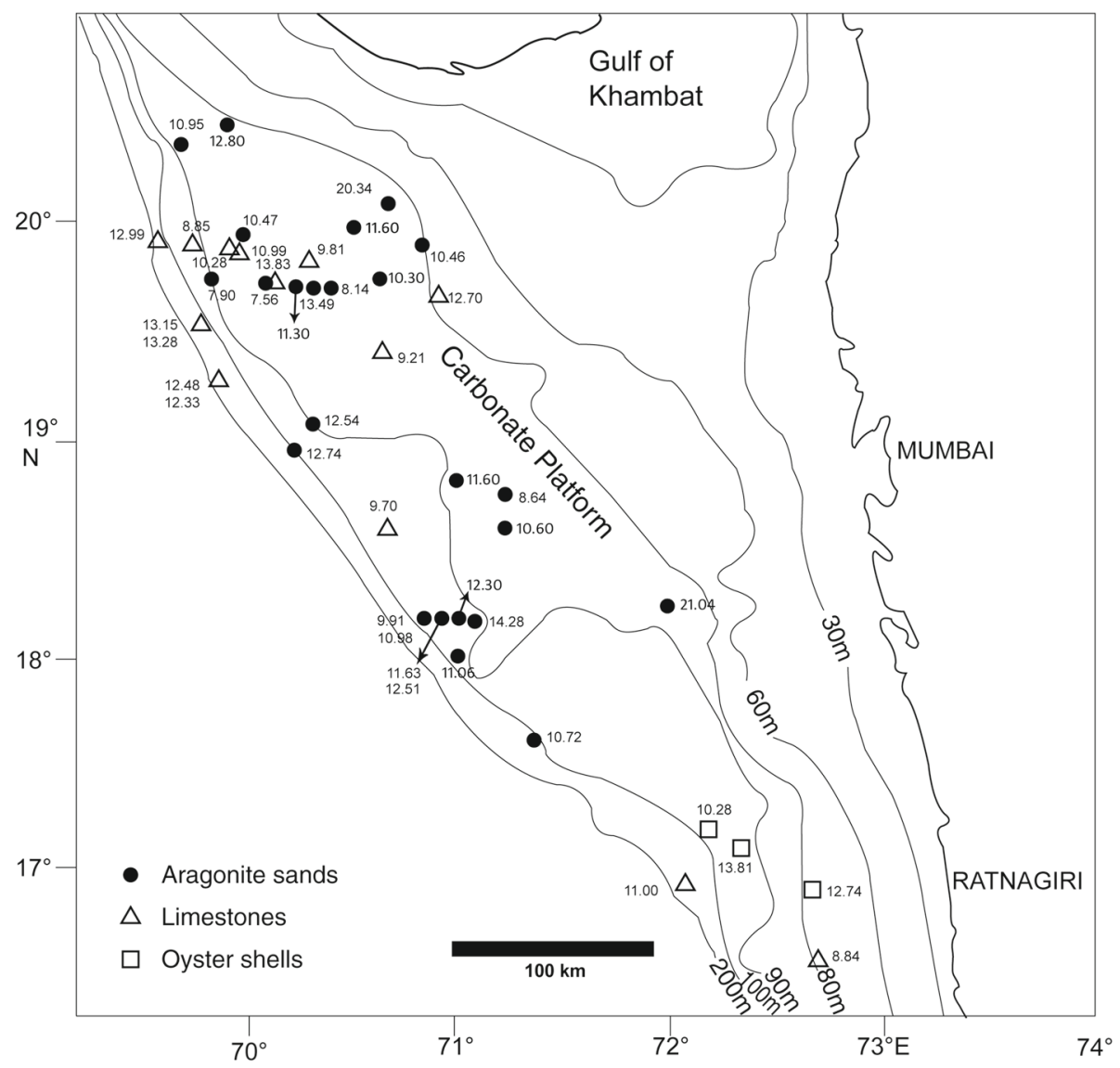

Figure 10. Calibrated radiocarbon ages (ka BP) of surficial sediments and sedimentary rocks on the carbonate platform and adjacent slope.

platform (figure 4). The asymmetry of the mounds (figure 4c) is because of strong growth, coalescence and fusing of smaller mounds on their seaward flanks. Small-scale surface ripples (figure 4c) suggest that the mounds were within the active zone of wave and current activity and reworking of surface sediment. Smoothened mound tops (figure 4a and e) are probably caused by surface erosion. In other words, the shape of the mounds and surface ripples may be interpreted to reflect high-energy settings during and after their formation. Henreit et al. (2011) indicated that strong bottom currents interact with the mounds in various ways from creating small sedimentary structures (ripples) to control the shape of a mound. Strong currents trigger sediment reworking and bedform formation and thus the ripples and coarse layers are indicative of reworking and/or erosion in the mound record.

Some of the organisms (in particular green algae) are used for bathymetric estimates for mound depositional environment. The sediments everywhere on the platform are sandy and comprise the crustacean faecal pellets and Halimeda (figure 9a and b), and shells and shell fragments dominated by pelecypods. The higher proportions of shells and shell fragments landward (figure 8b) indicate the suspended sediment feeders such as pelecypods grew more on the eastern portion of the platform may be because they are feeding on little suspended terrigenous sediment reaching from the east of the platform. Higher proportions of non-skeletal grains on the west of the platform (figure 8a) indicate the luxuriant biohermal growth and high carbonate sedimentation occurred at the seaward of the platform. Detailed investigations by Rao et al. (1994) indicated that the Halimeda plates were disintegrated into sand and mud fractions but the mud was fixed up by crustaceans in the form of faecal pellets and thus abundant aragonite faecal pellets on the platform. It is likely that some mud was transported onto the continental slope because of high-energy conditions, prevalent during the lowered sea levels and post-glacial rise. Rao et al. (2012) reported the lime mud-dominated sediments in sediment cores 
recovered from the continental slope and suggested that they are detrital and transported from the platform.

\subsection{Factors responsible for Halimeda growth}

The spatial distribution and morphology of the bioherms and associated sediments have implications for understanding the sources of nutrients for the biohermal growth. The Halimeda bioherms on the Kalukalukuang Bank (Roberts et al. 1987a, b; Roberts and Phipps 1988) and the Great Barrier Reef (Orme and Salama 1988) were developed in reef protected settings and their abundant growth was facilitated by upwelled, nutrient-rich oceanic waters intruded onto the outer shelf through narrow passages of Ribbon reefs. In contrast, the bioherms investigated here were developed in open marine settings, with no coral reef growth seaward. Moreover, the well-developed bioherms with abundant carbonate sands comprising $<10 \%$ terrigenous material suggest two important revelations: (a) The limited terrigenous sediment deposition onto the platform despite the huge sediment input expected from the Narmada and Tapi rivers during the early Holocene lowered sea levels implies that the sediments from these rivers have not reached the platform, may be because the platform was isolated from the western shelf until the early Holocene. Terrigenous sediments may have filled the inner shelf, which was a huge clastic depocentre - the Dahanu depression in which extensive prodelta silts and muds were deposited since the Eocene (Basu et al. 1980). Alternatively, the terrigenous sediments may have diverted southwards under the influence of southwest monsoon current. If the terrigenous material discharged by the Narmada and Tapi rivers ( $\sim 60$ million $\mathrm{m}^{3}$ of water and suspended sediment annually - Rao 1975) reached the platform during the early Holocene, it must have experienced turbid conditions that hindered and adversely affected the photosynthesis and flourishing of Halimeda bioherms. Littler et al. (1988) proposed the nutrient- and light-limited photosynthesis in Halimeda. In other words, little terrigenous sediment supply indeed favoured the Halimeda growth on the platform. (b) The luxuriant growth of bioherms, more on the western edge of the platform between 11,000 and $7500 \mathrm{yr}$ BP (surface ages of sediments - see figure 10), implies the supply of clear, nutrient-rich upwelled water from the offshore favoured their growth. Several investigators reported the intensified southwest monsoon winds and their associated upwelling between 13 and 6 ka BP (Prell 1984; Sirocko et al. 1993) on the west coast of India, more specifically between 11 and 10 ka BP (Kessarkar et al. 2013) and/or after 9-8 ka BP (Thamban et al. 2001, 2007). Intense upwelling brings excess nutrients to the surface and excess nutrients are detrimental to the carbonate sedimentation (Hallock and Schlager 1986; Hallock et al. 1988). Recent study indicated that the monsoon-induced upwelling is much more intense and active on the southwestern margin of India between $7^{\circ}$ and $14^{\circ} \mathrm{N}$ (Muni Krishna 2008) than on the carbonate platform, located between $17^{\circ}$ and $21^{\circ} \mathrm{N}$. It appears that the carbonate platform experienced moderate upwelling during the early Holocene and responsible for the luxuriant growth of Halimeda bioherms. The asymmetry of the mounds (figure 4c) may be due to higher growth seaward and suggests that the upwelled water from offshore facilitated significant growth. Hopley (1994) suggested high-nutrient levels and clear water favoured Halimeda growth on the Great Barrier Reef. Why reef growth stopped after $7.5 \mathrm{ka} \mathrm{BP}$ on the platform is unknown. Wolanski et al. (1988) suggested that $40-45 \mathrm{~m}$ deep water is necessary for the development of modern bioherms. Sea level rise after $7.5 \mathrm{ka} \mathrm{BP}$ is not much as sea level reached its present position around $7 \mathrm{ka} \mathrm{BP}$. Therefore, it is likely that the bioherms were affected by combination of factors, such as rising sea level or shift in upwelling centres after the early Holocene caused environmental stress and drown the platform after $7.5 \mathrm{ka} \mathrm{BP}$.

\subsection{Mass $\mathrm{CaCO}_{3}$ content}

Halimeda is the single most and dominant contributor of carbonate sediments on the platform and it is possible to estimate the mass calcium carbonate production. The Holocene bioherms in the Indo-Pacific region seem to be growing off the prominent reflector that corresponds to the late Pleistocene surface (Roberts et al. 1987a, b; Orme and Salama 1988). The prominent reflector is indistinct with the limited seismic data available on the platform (figure 7). Moreover, the thickness of the Halimeda bioherms is hard to assess because they form a series of sinuous ridges, troughs, banks and mounds (figures 2-6) and are transparent internally (figure 7). Bathymetric records, however, show that the height of the bioherms ranges between 2 and $20 \mathrm{~m}$ and the majority of bioherms 
are $10-15-\mathrm{m}$ height. The average height is $\sim 7 \mathrm{~m}$ and therefore considered as the average thickness $(T)$ of the bioherms for the estimation of mass calcium carbonate production. Despite the area $(A)$ occupied by the platform between 80 and $90-\mathrm{m}$ depth contours is $28,336 \mathrm{~km}^{2}$ (Rao et al. 1994), the bathymetric data are available only for 20,000 $\mathrm{km}^{2}$ area and this area was considered for the estimation of mass $\mathrm{CaCO}_{3}$. Since the sediments on the platform were largely derived from Halimeda, the density $(D)$ of sediments is considered as 2.9 $\mathrm{g} / \mathrm{cm}^{3}$, following Kinsey and Hopley (1991). The sediments are carbonate sands and their porosity $(P)$ is considered as $50 \%$. The calcium carbonate content of the sediments $(C)$ is $90 \%$ because the sediments comprise $<10 \%$ terrigenous minerals.

The mass calcium carbonate $(M)$ production on the platform can be estimated by the equation (Rees et al. 2007)

$$
M=A \times T \times D \times P \times C,
$$

where $A$ is the area of the platform; $T$ is the thickness of the bioherms; $D$ is the density; $P$ is the porosity and $C$ is the carbonate content of the sediments. Since the calibrated radiocarbon ages of carbonate sediments of the platform mostly ranges between 11 and $7.5 \mathrm{ka} \mathrm{BP}$, we presumed that the growth of Halimeda bioherms was high during this period. It is a reasonable assumption because the sediments older than $11 \mathrm{ka} \mathrm{BP}$ (figure 10) are found from the floor of the platform, rather than from the biohermal structures.

Using the above equation, it is estimated that the platform contains $1.827 \mathrm{Gt}$ of mass carbonate produced in $3500 \mathrm{yr}$, i.e., between 11,000 and 7500 yr BP. It has been reported that the global Halimeda bioherms contain 180 Gt of mass carbonate, and Halimeda bioherms in the NGBR contain 3.9 Gt of mass carbonate accumulated during the entire Holocene (Rees et al. 2007). In other words, the mass carbonate produced in $3500 \mathrm{yr}$ on the carbonate platform is very significant, because we have considered only part of the area on the platform and the average thickness as $7 \mathrm{~m}$, despite bioherms up to $20 \mathrm{~m}$ were found on the platform (figures 2-4). If the complete area of the platform is surveyed with ORE sub-bottom profiler, the mass $\mathrm{CaCO}_{3}$ content must be much higher and close to that of the Great Barrier Reef. The platform thus contributed significantly to the global carbonate system during the early Holocene. Since marine carbonate production releases $\mathrm{CO}_{2}$ and rises atmospheric $\mathrm{CO}_{2}$ levels, the $\mathrm{CO}_{2}$ content released to the atmosphere must have been high during the growth period of Halimeda bioherms, i.e., during the early Holocene. This is because of isolated platform conditions and moderate upwelling during the early Holocene. For the exact quantification of mass $\mathrm{CaCO}_{3}$ content, good seismic records and long sediment cores are to be obtained from the platform. A systematic study of the platform is essential in the present scenario of global rise in carbon dioxide content and modelling climatic conditions. Organisations such as the CSIR-National Institute of Oceanography and Ministry of Earth Sciences, India may realise the importance of Halimeda bioherms and come forward to take up this challenging programme.

\section{Acknowledgements}

The authors thank the Director, CSIR-National Institute of Oceanography (CSIR-NIO), Goa for providing facilities and encouragement. Multibeam bathymetry was collected under Exclusive Economic Zone (EEZ) Project to Dr B Chakraborty, funded by the Ministry of Earth Sciences, New Delhi. We thank Dr B G Wagle and Dr S M Karisiddaiah for the bathymetric data. Dr Rao thanks Vignan's University for providing facilities to execute writing of this paper.

\section{References}

Basu D N, Banerjee A and Tamhane D M 1980 Source areas and migration trends of oil and gas in Bombay offshore Basin, India; Am. Assoc. Petrol. Geol. Bull. 64209 220 .

Braga J C and Martin J M 1993 Halimeda bioherms in Messinian basinal sequences: Fossil analogues of modern Australian examples; In: International Symposium on Alpine Algae, Abstracts, Munich, University of Munich, $94 \mathrm{p}$.

Braga J C, Martin J M and Riding R 2015 Internal structure of segment reefs: Halimeda algal mounds in the Mediterranean Miocene; Geology 24 35-38.

Drew E A and Abel K M 1985 Biology, sedimentology and geography of the vast inter-reefal Halimeda meadows within the Great Barrier Reef province; In: Proceedings of the Fifth International Coral Reef Congress, 5, pp. 15-20.

Elliot G F 1965 The inter-relationships of some Cretaceous Codiaceae (calcareous algae); Palaeontology 8 199-203.

Fornos J J, Forteza V and Jaume C 1992 Present-day Halimeda carbonate sediments in temperate Mediterranean embayments: Fornells, Balearic Islands; Sedim. Geol. $\mathbf{7 5}$ 283-293. 
Freile D 2004 Carbonate productivity rates of Halimeda in two different locations, San Salvador Island, Bahamas; In: Proceedings of the 11th Symposium on the Geology of the Bahamas and other Carbonate Regions (eds) Lewis R D and Panuska B C, Gerace Research Center, San Salvador, Bahama; Production Center, Auburn University, Auburn, AL, pp. 95-106.

Hallock P, Hine A C, Vargo G A, Elrod J A and Japp W J 1988 Platforms of nicaraguan rise: Examples of the sensitivity of carbonate sedimentation to excess trophic resources; Geology 16 1104-1107.

Hallock P and Schlager W 1986 Nutrient excess and the demise of coral reefs and carbonate platforms; Palaios 1 389-398.

Harris P T, Pattiaratchi C B, Keene J B, Dalrymple R W, Gardner J V, Baker E K, Cole A R. Mitchell D, Gibbs P and Schroeder W W 1996 Late quaternary deltaic and carbonate sedimentation in the Gulf of Papua foreland basin: Response to sea-level change; J. Sedim. Res. A 66 4801-4819.

Hay M E, Paul V J, Lewis S M, Gustafson K, Tucker J and Trindell R N 1988 Can tropical seaweeds reduce herbivory by growing at night? Diel patterns of growth, nitrogen content, herbivory, and chemical versus morphological defenses; Oecologia 75 233-245.

Henriet J-P, Spezzaferri S, Samankassou E, Foubert A, Van Rooij D and Rüggeberg A 2011 Carbonate mounds in shallow and deep time; Mar. Geol. 282 1-4.

Heyward A, Pinceratto E and Smith L D 1997 Big bank shoals of the Timor sea: An environmental resource atlas; Australian Institute of Marine Science and BHP Petroleum, Townsville, Australia, 95p.

Hillis-Colinvaux L 1980 Ecology and taxonomy of Halimeda: Primary producer of coral reefs; Adv. Mar. Biol. 17 1-327.

Hillis-Colinvaux L 1986 Halimeda growth and diversity on the deep forereef of Eniwetak Atoll; Coral Reefs 5 19-21.

Hillis L 1997 Coralgal reefs from a calcareous green alga perspective and a first carbonate budget; In: Proceedings of the Eighth International Coral Reef Symposium, 1, pp. 761-766.

Hine A C, Hillock P, Harris M W, Mullins H T, Belknap D F and Jaap W C 1988 Halimeda bioherms along an open seaway: Miskito channel, Nicaraguan rise, SW Caribbean Sea; Coral Reefs 6 173-178.

Hopley D 1994 Continental shelf reef systems. In: Coastal evolution, late Quaternary shoreline morphodynamics (eds) Carter R W G and Woodroffe C D, Cambridge University Press, Cambridge, pp. 303-340.

Hoskin C M, Reed J K and Mook D H 1986 Production and off-bank transport of carbonates sediment, black rock, southwest little Bahama bank; Mar. Geol. 73 125144.

Kessarkar P M, Rao V P, Naqvi S W A and Karapurkar S G 2013 Variation in the Indian summer monsoon intensity during the Bølling-Ållerød and Holocene; Paleoceanography 28 413-425.

Kirkland B L, Moore C H Jr and Dickson J A D 1993 Well preserved aragonite algae (Eugonophyllum U'doteaceae) from the Pennsylvanian holder formation, Sacramento mountains, New Mexico; Palaios 8 111-120.

Liddell W D, Ohlhorst S L and Boss S K 1988 The significance of Halimeda as a space-occupier and sediment-producer, 1-750 m; In: The Sixth International Coral Reef Symposium (Abstract), North Jamaica, 63p.

Littler M M, Littler D S and Lapointe B E 1988 A comparison of nutrient- and light-limited photosynthesis in psammophytic versus epilithic forms of Halimeda (Caulerpales, Halimedaceae) from the Bahamas; Coral Reefs 6 219-225.

Marshall J F and Davies P J 1988 Halimeda bioherms of the northern Great Barrier Reef; Coral Reefs 6 139148.

Milliman J D 1974 Recent Sedimentary Carbonates, Part I, Marine Carbonates; Springer, Berlin, Heidelberg, New York, 375p.

Milliman J D 1993 Production and accumulation of calcium carbonate in the ocean: Budget of a non-steady state; Global Biogeochem. Cycles 7 927-957.

Multer H G 1988a Growth rate, ultrastructure and sediment contribution of Halimeda incrassata and Halimeda monile, Nonsuch and Falmouth Bays, Antigua, W.I.; Coral Reefs 6 179-186.

Multer H G 1988b Notes on stress-recovery, abnormal growth, stabilization mechanisms and segment preservation of Halimeda, Antigua, W.I.; In: The Sixth International Coral Reef Symposium (Abstract), 74p.

Muni Krishna K 2008 Coastal upwelling along the southwest coast of India - ENSO modulation; Ann. Geophys. 26 1331-1334.

Nair R R 1971 Beach rock and associated carbonate sediments on the fifty fathom flat, a submarine terrace on the outer continental shelf of Bombay; Proc. Indian Acad. Sci. Sect. B 73 148-154.

Nair R R 1975 Nature and origin of small scale topographic prominences on the western continental shelf of India; Indian J. Mar. Sci. 4 25-29.

Nair R R and Hashimi N H 1981 Mineralogy of the carbonate sediments western continental shelf of India; Mar. Geol. 41 309-319.

Nair R R and Pylee A 1968 Size distribution and carbonate content of the sediments of the western shelf of India; Bull. Natl. Inst. Sci. India 38 411-420.

Nair R R, Hashimi N H and Guptha M V S 1979 Holocene limestones of part of the western continental shelf of India; J. Geol. Soc. India 20 17-23.

Nair R R, Hashimi N H and Rao V P 1982 On the possibility of high-velocity tidal streams as dynamic barriers to longshore sediment transport: Evidence from the continental shelf off the Gulf of Kutch, India; Mar. Geol. 47 77-86.

Orme G R 1985 The sedimentological importance of Halimeda in the development of back-reef lithofacies, northern Great Barrier Reef (Australia); In: Proceedings of the Fifth International Coral Reef Congress, Tahiti, 5, pp. 31-37.

Orme G R, Flood P G and Sargent G E G 1978 Sedimentation trends in the lee of the outer (ribbon) reefs, northern region of the Great Barrier Reef Province; Phil. Trans. Roy. Soc. London A 291 85-99.

Orme G R and Salama M S 1988 Form and seismic stratigraphy of Halimeda banks in part of the northern Great Barrier Reef Province; Coral Reefs 6 131-137.

Overholtzer K L and Motta P J 1999 Comparative resource use by juvenile parrot fishes in the Florida Keys; Mar. Ecol. Prog. Ser. 177 177-187. 
Paul V J and van Alstyne K L 1988 Antiherbivore defenses in Halimeda: Effects against generalist and specialist herbivores; In: The Sixth International Coral Reef Symposium (Abstract), 78p.

Pennings S C and Paul V J 1992 Effect of plant toughness, calcification, and chemistry on herbivory by Dolabella auricularia; Ecology 73 1606-1619.

Phipps C V G, Davies P J and Hopley D 1985 The morphology of Halimeda banks behind the Great Barrier Reef east of Cooktown, Queensland; In: The Fifth International Coral Reef Symposium, 5, pp. 27-30.

Phipps C V G and Roberts H H 1988 Characteristics and environments formation of Indonesian Halimeda bioherms; In: The Sixth International Coral Reef Symposium, $79 \mathrm{p}$.

Pratt B R 1995 The origin, biota and evolution of deep-water mudmounds. In: Carbonate Mud-Mounds: Their Origin and Evolution (eds) Monty C L V, Bosence D WJ, Bridges P H and Pratt B R, Int. Assoc. Sedimentol. Spec. Publ. 23 49-123.

Prell W L 1984 Variation of monsoonal upwelling: A response change in varved sediments from the oxygen minimum to changing solar radiation; In: Climate Processes and Climate Sensitivity (eds) Hansen J E and T Takahashi, Geophysics, AGU, Washington DC, $5 \mathbf{1}$ 39-53.

Price N N, Hamilton S L, Tootell J S and Smith J E 2011 Species-specific consequences of ocean acidification for the calcareous tropical green algae Halimeda; Mar. Ecol. Progr. Ser. 140 67-78.

Rao K L 1975 India Water Wealth, Orient Longman, New Delhi, 255p.

Rao V P and Veerayya M 1996 Submarine terrace limestones from the continental slope off Saurashtra-Bombay: Evidence of late quaternary neotectonic activity; Curr. Sci. 71 36-41.

Rao V P, Anil Kumar A, Naqvi S W A, Chivas A R, Sekar B and Kessarkar P M 2012 Lime muds and their genesis offNorthwestern India during the late quaternary; J. Earth Syst. Sci. 121 769-779.

Rao V P, Kessarkar P M, Krumbein W E, Krajewski K P and Schneider R J 2003a Microbial dolomite crusts from the carbonate platform off western India; Sedimentology 50 819-830.

Rao V P, Montaggionni L, Vora K H, Almeida F, Rao K M and Rajagopalan G 2003b Significance of relict carbonate deposits along the central and southwestern margin of India for environmental and sea level changes; Sed. Geol. 159 95-111.

Rao V P and Milliman J D 2017 Relict ooids off northwestern India: Inferences on their genesis and late quaternary sea level; Sed. Geol. 358 44-50.

Rao V P, Veerayya M, Nair R R, Dupeuble P A and Lamboy M 1994 Late quaternary Halimeda bioherms and aragonitic faecal pellet-dominated sediments on the carbonate platform of the western continental shelf of India; Mar. Geol. 121 293-315.
Rees S A, Opdyke B N, Wilson P A and Field L K 2005 Coral reef sedimentation on Rodrigues and the western Indian ocean and its impact on the carbon cycle; Phil. Trans. Roy. Soc. London A 363 101-120.

Rees S A, Opdyke B N, Wilson P A and Henstock T J 2007 Significance of Halimeda bioherms to the global carbonate budget based on a geological sediment budget for the northern great barrier reef, Australia; Coral Reefs 26 177188.

Riding R 2002 Structure and composition of organic reefs and carbonate mud mounds: Concepts and categories; Earth Sci. Rev. 58 163-231.

Roberts H H and Phipps C V 1988 Proposed oceanographic controls on modern Indonesian reefs: A turn on/turn off mechanism in a monsoonal setting; In: The Sixth International Coral Reef Symposium, 87p.

Roberts H H, Phipps C V and Effendi L 1987a Halimeda bioherms of the eastern Java Sea, Indonesia; Geology 15 371-374.

Roberts H H, Phipps C V and Effendi L 1987b Morphology of large Halimeda bioherms, eastern Java sea (Indonesia): A side scan sonar study; Geo-Mar. Lett. 7 7-14.

Roberts H H, Aharon P and Phipps C V 1988 Morphology and sedimentology of Halimeda bioherms from the eastern Java sea (Indonesia); Coral Reefs 6 161-172.

Scoffin T P and Tudhope A W 1985 Sedimentary environments of the central region of the great barrier reef of Australia; Coral Reefs 4 81-93.

Searle D E and Flood P G 1988 Halimeda bioherms of the Swain Reefs - Southern Great Barrier Reef; In: The Sixth International Coral Reef Symposium, 92p.

Sirocko F, Sarnthein M, Erlenkeuser H, Lange H, Arnold M and Duplessy J C 1993 Century-scale events in monsoonal climate over the past 24,000 years; Nature 364 322-324, https://doi.org/10.1038/364322a0.

Thamban M, Kawahata H and Rao V P 2007 Indian summer monsoon variability during the Holocene as recorded in sediments of the Arabian Sea: Timing and implications; J. Ocean 63 1009-1020.

Thamban M, Rao V P, Schneider R R and Grootes P M 2001 Glacial to Holocene fluctuations in hydrography and productivity along the southwestern continental margin of India; Palaeogeogr. Palaeoclimatol. Palaeoecol. 165113 127.

Wefer G 1980 Carbonate production by algae Halimeda, Penicillus and Padina; Nature 285 323-324.

Wolanski E J, Drew E A, Abel K M and O'Brien J 1988 Tidal jets, nutrient upwelling and their influence on the productivity of the alga Halimeda in the Ribbon Reefs, Great Barrier Reef; East. Coast. Shelf. Sci. 26 169-201.

Wood R 2001 Are reefs and mud mounds really so different? Sedim. Geol. 145 161-171.

Xu H, Zhao X, Eberli G P, Liu X, Zhu Y, Cai Y, Luo W, Yan B G, Zhang B, Wei K and Shi J 2015 Biogenic carbonate formation and sedimentation in the Xisha Islands: Evidences from living Halimeda; Acta Oceanol. Sin. 34 $62-73$. 